NBER WORKING PAPER SERIES

\title{
HOW ORDINARY CONSUMERS MAKE COMPLEX ECONOMIC DECISIONS: FINANCIAL LITERACY AND RETIREMENT READINESS
}

\author{
Annamaria Lusardi \\ Olivia S. Mitchell \\ Working Paper 15350 \\ http://www.nber.org/papers/w15350 \\ NATIONAL BUREAU OF ECONOMIC RESEARCH \\ 1050 Massachusetts Avenue \\ Cambridge, MA 02138 \\ September 2009
}

This research was supported by a grant from the U.S. Social Security Administration (SSA) as part of the Retirement Research Consortium (RRC). Additional support from the US Department of Labor, the FINRA Investor Education Foundation, and the Pension Research Council at the Wharton School is gratefully acknowledged. Useful comments and data suggestions were provided by Sandy Chien, Jeff Dominitz, Angela Hung, Arie Kapteyn, Karen Pence, Scott Weisbenner, Joanne Yoong, and participants to seminars at Bocconi University, the 2009 NBER Summer Institute, the NBER meeting on Economics of Household Saving, and the 2009 Retirement Research Consortium meeting in Washington, D.C. Arthur van Soest provided invaluable help in devising the financial literacy questions. Yuni Yan, Hiroaki Matsuura, and Vilsa Curto provided excellent research assistance. Findings and conclusions expressed are solely those of the authors and do not represent the views of SSA, any agency of the Federal Government or the RRC. The views expressed herein are those of the author(s) and do not necessarily reflect the views of the National Bureau of Economic Research.

NBER working papers are circulated for discussion and comment purposes. They have not been peerreviewed or been subject to the review by the NBER Board of Directors that accompanies official NBER publications.

(C) 2009 by Annamaria Lusardi and Olivia S. Mitchell. All rights reserved. Short sections of text, not to exceed two paragraphs, may be quoted without explicit permission provided that full credit, including (C) notice, is given to the source. 
How Ordinary Consumers Make Complex Economic Decisions: Financial Literacy and Retirement Readiness

Annamaria Lusardi and Olivia S. Mitchell

NBER Working Paper No. 15350

September 2009

JEL No. D91

$\underline{\text { ABSTRACT }}$

This paper reports on several self-assessed and objective measures of financial literacy newly added to the American Life Panel (ALP), and it links these performance measures to efforts consumers make to plan for retirement. We evaluate the causal relationship between financial literacy and retirement planning by exploiting information about respondents' financial knowledge acquired in school - before entering the labor market and certainly before starting to plan for retirement. Results show that those with more advanced financial knowledge are those more likely to be retirement-ready.

\author{
Annamaria Lusardi \\ Department of Economics \\ Dartmouth College \\ Hanover, NH 03755 \\ and NBER \\ a.lusardi@dartmouth.edu \\ Olivia S. Mitchell \\ University of Pennsylvania \\ Wharton School \\ 3620 Locust Walk, St 3000 SH-DH \\ Philadelphia, PA 19104-6302 \\ and NBER \\ mitchelo@wharton.upenn.edu
}




\title{
How Ordinary Consumers Make Complex Economic Decisions: Financial Literacy and Retirement Readiness
}

\author{
Annamaria Lusardi and Olivia S. Mitchell
}

There can hardly be a better time to make the case for economic and financial literacy... a better-informed citizenry would likely have resulted in more prudent decision making and, consequently, less harm to the economy. ${ }^{1}$

Ordinary consumers must make extraordinarily complex financial decisions on a daily basis, yet there is now growing evidence that households are rather poorly informed when they make many consequential economic choices. ${ }^{2}$ Prior surveys reveal that financial illiteracy is widespread among older individuals: only half of Americans age 50+ can correctly answer two simple questions about compound interest and inflation; only one-third can answer these two questions and another question on risk diversification. ${ }^{3}$ Financial literacy is also lacking among the young; less than half of young adults (ages 23-27) understand interest compounding, inflation, and risk diversification (Lusardi, Mitchell and Curto, 2008). Most importantly, there is evidence that the least financially literate are the least likely to save for retirement (Lusardi and Mitchell, 2006, 2007a, 2008).

This paper examines the questions of who is financially literate, whether people accurately perceive their own economic decision-making skills, and where these skills come from. To this end, we have designed and implemented a new set of questions on both financial literacy and retirement planning for respondents to the American Life Panel (ALP), where we are able to measure financial literacy in a more sophisticated manner than heretofore feasible. This

\footnotetext{
${ }^{1}$ Mishkin (2008).

2 See Campbell (2006), Bucks and Pence (2008), Moore (2003), Gustman, Steinmeier and Tabatabai (2008), and the discussion in Lusardi (2008).
} 
dataset also permits us to link these improved objective measures with respondents' self-assessed financial knowledge levels, and to compare what people know with what they think they know. Most importantly, we seek to identify the causal links between financial literacy and retirement planning by exploiting information about respondents' financial knowledge acquired in school before entering the labor market and certainly before starting to plan for retirement.

Our results show that consumers have difficulty doing basic financial calculations, and they also lack knowledge of fundamental financial market concepts such as risk diversification, how the stock market works, and asset pricing. We also find that people who report a higher level of knowledge of economics tend to score relatively well on the objective measures we gather. And finally, we show that financial literacy contributes importantly to retirement readiness, after correcting for potential endogeneity biases.

Our work makes three contributions to the existing literature. First, we enhance the existing measures of financial literacy by providing not only an extensive set of questions to measure financial literacy but also by assessing the quality of the data. Second, we are able to explain why so many individuals do not plan for retirement; we find that lack of financial knowledge is a cause of lack of retirement planning. Third, our data collected before the financial crisis erupted provide clear warnings about lack of financial knowledge in the population and the potential vulnerability of individuals who lack a firm grasp of basic financial concepts.

\footnotetext{
${ }^{3}$ Lusardi and Mitchell (2006). See also Bernheim (1995, 1998), Hilgert, Hogarth and Beverly (2003), the National Council on Economic Education (2005), Mandell (2008), the OECD Report on Financial Literacy (2005), and
} 


\section{Background}

The theoretical framework used to model consumption/saving decisions posits that rational and foresighted consumers derive utility from consumption over their lifetimes. In the simplest format, the consumer has a lifetime expected utility, which is the expected value of the sum of per-period utility $U\left(c_{j}\right)$ discounted to the present (using the discount factor $\beta$ ), multiplied by the probability of survival $p_{j}$, from the worker's current age $S$ to the oldest possible lifetime $D$ :

$$
E\left[\sum_{j=S}^{D} p_{j} \beta^{j-S} U\left(c_{j}\right)\right] .
$$

Assets and consumption each period $\left(a_{j}\right.$ and $\left.c_{j}\right)$ are determined endogenously by maximizing this function subject to an intertemporal budget constraint. Thus $c_{j}$ represents per period consumption, $e_{j}$ is labor earnings, $r a_{j}$ represents the household's returns on assets $a_{j}, y_{j}$ is income, and $S S$ and $P P$ represent the household's Social Security benefits and pensions, respectively, which depend on the worker's retirement age, $R$ :

$$
\begin{aligned}
& y_{j}=e_{j}+r a_{j}, j \in[S, \ldots, R-1] \\
& \text { and } \\
& y_{j}=S S_{j}(R)+P P_{j}(R)+r a_{j}, j \in[R, \ldots, D] .
\end{aligned}
$$

Furthermore, consumption from income, assets, and benefits is set so that:

$$
c_{j}+a_{j+1}=y_{j}+a_{j}, j \in[S, \ldots, D]^{4}
$$

In other words, the economic model posits that the consumer has to consider prospective survival probabilities, discount rates, investment returns, earnings, pensions and Social Security benefits.

Lusardi and Mitchell (2007a, 2007b).

${ }^{4}$ There is also the condition that assets in the last period of life are equal to zero and that the consumer does not die leaving any debt. 
Further, it posits that he/she uses that information to formulate and execute optimal consumption/saving plans.

This formulation makes it clear that consumers making retirement saving decisions require substantial financial literacy, in addition to the ability and tools needed to plan and carry out retirement saving plans. Whether and how consumers behave in reality when confronted with this challenge - that is, whether individuals have the knowledge and capability to plan and implement these complex planning tasks - is a topic of substantial current interest. ${ }^{5}$ This subject is particularly important in view of the fact that workers are increasingly being given responsibility to save, manage their pension investments, and draw down their retirement assets in the defined contribution pension environment. Accordingly, what is critically needed is new information permitting analysts to investigate the links between financial literacy and economic decision-making.

The Health and Retirement Study (HRS), a nationally representative longitudinal dataset of Americans over the age of 50, has been designed to address some of these questions by tracking health, assets, liabilities, and patterns of wellbeing in older households. ${ }^{6}$ Beginning in 1992, a 90-minute core questionnaire has been administered every two years to age-eligible respondents and their spouses. In addition, a random sample of respondents has also been subjected to very short experimental modules in each wave, aimed at helping researchers assess additional topics of substantive interest. For the 2004 HRS wave, we designed and administered a special module on financial literacy and retirement planning, seeking to assess respondents'

\footnotetext{
${ }^{5}$ See, for example, the discussion in Campbell (2006) and Lusardi (2008). Note also that many countries have started to collect data to measure citizens' financial capability. For instance, the UK started a new survey on financial capability a few years ago, and similar surveys have been done or are under way in Ireland, the Netherlands, Italy, New Zealand, Australia, Canada and the United States.

${ }^{6}$ For further detail see http://hrsonline.isr.umich.edu/.
} 
level of financial literacy along with their efforts to budget, calculate, and develop retirement saving plans, in relatively few questions (Lusardi and Mitchell, 2006).

The three questions on financial literacy we designed, which have by now become standard in assessing economic literacy and are included in many other surveys in the United States and abroad, are as follows: ${ }^{7}$

- Suppose you had $\$ 100$ in a savings account and the interest rate was 2 percent per year. After 5 years, how much do you think you would have in the account if you left the money to grow: more than $\$ 102$, exactly $\$ 102$, or less than $\$ 102$ ?

- Imagine that the interest rate on your savings account was 1 percent per year and inflation was 2 percent per year. After 1 year, would you be able to buy more than, exactly the same as, or less than today with the money in this account?

- Do you think that the following statement is true or false? "Buying a single company stock usually provides a safer return than a stock mutual fund."

The first two items indicate whether respondents are aware of compound interest and inflation, fundamental concepts required for making saving decisions. The third evaluates respondents' knowledge of risk diversification, also crucial for making informed decisions.

We found strikingly low performance on these basic financial literacy questions. For instance, one-fourth responded incorrectly to the first question. The accuracy rate for the second question was higher ( 75 percent correct), but only slightly over half (56 percent) got both answers correct, indicating a very poor level of basic knowledge in this older population. Moreover, only half (52 percent) of the respondents correctly answered the risk diversification question, and one-third (34 percent) said they did not know (Lusardi and Mitchell, 2006). These are important findings since correct responses to these simple questions are strongly associated with successful retirement planning: those who cannot do a simple interest calculation, do not

\footnotetext{
${ }^{7}$ For example, these questions have been added to the U.S. National Longitudinal Survey of Youth, a survey of U.S. pension providers, the 2005 Dutch Household Survey, the 2006 Italian Survey of Household Income and Wealth, the 2008 World Bank Russia Financial Literacy and Financial Education Survey, the 2009 German SAVE, the 2009
} 
know about inflation and risk diversification are also much less likely to calculate how much they need to save for retirement (Lusardi and Mitchell, 2006, 2008).

Several research questions remain outstanding, which we address below. We believe it imperative to expand the range of measures of financial literacy, so as to better evaluate the types of problems that people find most difficult. It is also important to determine whether people are aware of their areas of weakness. And finally, much prior research, including all our own work with the HRS, focused only on those in the $50+$ age group; in what follows we expand our purview to the entire population.

\section{Data and Methodology}

In this paper, we use data from the Rand American Life Panel (ALP). This is an Internetbased survey of respondents age 18+ recruited by the University of Michigan's Survey Research Center. ${ }^{8}$ Using the internet to collect data is desirable in that it permits respondents to read questions on the screen and reflect upon them before responding. Moreover, this approach to data collection permits the researcher to alter how questions are framed so as to assess whether and how people understand the questions posed.

The ALP survey collects numerous socioeconomic variables (age, sex, marital status, race/ethnicity, and income). In addition, we have devised a set of financial literacy and planning questions aimed at households in their prime earning years, as we seek to assess the information sets available to them when they make some of these critical financial decisions. Specifically, we

New Zealand Financial Knowledge Survey, a survey of pension funds in Mexico, and a survey of entrepreneurs in Sri Lanka.

${ }^{8}$ This sample was recruited from former participants in the Survey of Consumer Attitudes used to generate Michigan's Index of Consumer Expectations. ALP participants use their own computers or a Web TV to log on to the Internet monthly where they are asked to complete an online survey lasting no more than half an hour at a time. The initial sample had relatively high education and income; this paper uses sample weights to make the respondents representative of the U.S. population. For more information see www.rand.org/labor/roybalfd/american_life.html. 
seek to differentiate levels of financial knowledge and also collect information on both objective and subjective measures of financial literacy. Most importantly, we have variables that can help assess the effects of financial literacy on behavior.

We use two sets of questions to test for economic knowledge. The first set follows the HRS approach, which captures people's capacity to handle basic financial literacy concepts, including compound interest, inflation, and the time value of money. The second set is intended to capture sophisticated financial literacy; here we seek to measure more advanced financial knowledge such as the risk/return difference between stocks and bonds, how the stock market and risk diversification work, and the relationship between bond prices and interest rates.

The precise wording of the five basic financial literacy questions we ask in the ALP is as follows: ${ }^{9}$

\section{Basic Financial Literacy Questions}

1. Numeracy

Suppose you had $\$ 100$ in a savings account and the interest rate was 2 percent per year. After 5 years, how much do you think you would have in the account if you left the money to grow? (i) More than \$102; (ii) Exactly \$102; (iii) Less than \$102; (iv) Do not know (DK); (v) Refuse.

\section{Compound Interest}

Suppose you had $\$ 100$ in a savings account and the interest rate is 20 percent per year and you never withdraw money or interest payments. After 5 years, how much would you have on this account in total? (i) More than \$200; (ii) Exactly \$200; (iii) Less than \$200; (iv) DK;

(v) Refuse.

3. Inflation

Imagine that the interest rate on your savings account was 1 percent per year and inflation was 2 percent per year. After 1 year, how much would you be able to buy with the money in this account? (i) More than today; (ii) Exactly the same; (iii) Less than today; (iv) DK; (v) Refuse.

4. Time Value of Money

Assume a friend inherits $\$ 10,000$ today and his sibling inherits $\$ 10,0003$ years from now. Who is richer because of the inheritance? (i) My friend; (ii) His sibling; (iii) They are equally rich; (iv) DK; (v) Refuse.

\section{Inflation/Money Illusion}

\footnotetext{
${ }^{9}$ As previously noted, two questions were piloted in the 2004 HRS; see Lusardi and Mitchell (2006). The additional questions were piloted in the 2005 Dutch DNB Household Survey; see van Rooij, Lusardi and Alessie (2007).
} 
Suppose that in the year 2010, your income has doubled and prices of all goods have doubled too. In 2010, how much will you be able to buy with your income? (i) More than today; (ii) The same; (iii) Less than today; (iv) DK; (v) Refuse.

In addition, competent planning for retirement and investing of retirement assets requires several additional financial concepts, including an understanding of the risk/return relationship, risk diversification, and how stocks and bonds work. To quantify how sophisticated people are in this realm, we devised eight additional questions. The exact wording of these sophisticated questions is as follows: ${ }^{10}$

\section{Sophisticated Financial Literacy Questions}

1. Stock Market Functioning

Which of the following statements describes the main function of the stock market? (i) The stock market helps to predict stock earnings; (ii) The stock market results in an increase in the price of stocks; (iii) The stock market brings people who want to buy stocks together with those who want to sell stocks; (iv) None of the above; (v) DK; (vi) Refuse.

2. Knowledge of Mutual Funds

Which of the following statements is correct? (i) Once one invests in a mutual fund, one cannot withdraw the money in the first year; (ii) Mutual funds can invest in several assets, for example invest in both stocks and bonds; (iii) Mutual funds pay a guaranteed rate of return which depends on their past performance; (iv) None of the above; (v) DK; (vi) Refuse.

3. Interest Rate/Bond Prices Link

If the interest rate falls, what should happen to bond prices? (i) Rise; (ii) Fall; (iii) Stay the same; (iv) None of the above; (v) DK; (vi) Refuse.

4. Safer: Company Stock or Mutual Fund

True or false? Buying a company stock usually provides a safer return than a stock mutual fund. (i) True; (ii) False; (iii) DK; (iv) Refuse.

5. Riskier: Stocks or Bonds

True or false? Stocks are normally riskier than bonds. (i) True; (ii) False; (iii) DK; (iv)

Refuse.

6. Long Period Returns

Considering a long time period (for example 10 or 20 years), which asset normally gives the highest return? (i) Savings accounts; (ii) Bonds; (iii) Stocks; (iv) DK; (vi) Refuse.

7. Highest Fluctuation/Volatility

Normally, which asset displays the highest fluctuations over time? (i) Savings accounts; (ii) Bonds; (iii) Stocks; (iv) DK; (v) Refuse.

8. Risk Diversification

When an investor spreads his money among different assets, does the risk of losing money:

(i) Increase; (ii) Decrease; (iii) Stay the same; (iv) DK; (v) Refuse.

\footnotetext{
${ }^{10}$ One question was introduced in the 2004 HRS and the remaining questions were in the 2005 Dutch DNB Household Survey. See Lusardi and Mitchell (2006) and van Rooij, Lusardi and Alessie (2007).
} 
To further assess whether respondents actually understand the questions posed (versus simply guessing the answers), we take advantage of the Internet format to randomly reverse the question wording order for three questions: Q5, the simpler question about risk differences between bonds and stocks; Q4, a more difficult question about risk diversification; and Q3, the most difficult question about the link between bond prices and interest rates. Specifically, these word reversals are as reported below:

\section{Randomization of Word Order for Three Sophisticated Financial Literacy Questions Q5. True or false?}

(a) Stocks are normally riskier than bonds.

(b) Bonds are normally riskier than stocks.

Q4. True or false?

(a) Buying a company stock usually provides a safer return than a stock mutual fund.

(b) Buying a stock mutual fund usually provides a safer return than a company stock.

Q3. Rise/fall/stay the same/none of the above?

(a) If the interest rate falls, what should happen to bond prices?

(b) If the interest rate rises, what should happen to bond prices?

In addition to these factual questions, we also ask the following summary selfassessment: On a scale from 1 to 7, where 1 means very low and 7 means very high, how would you assess your understanding of economics? This is intended to assess people's confidence about the factual questions above, as well as what they believe they know about other financial concepts and financial instruments (e.g. mortgages, credit cards, etc.).

A crucial question is what might explain people's different levels of financial literacy. To glean a better understanding of how people might acquire financial literacy capital, we explore two possible sources of exposure to financial education early in the lifetime, namely exposure in school and in the workplace. Accordingly, we ask respondents about whether they were exposed to financial training during youth, well before they enter the job market and begin planning for retirement. This is elicited with the following query: How much of your school's education (high 
school, college or higher degrees) was devoted to economics? A lot, some, little, or hardly at all? Next, we ask respondents about their exposure to financial education in the workplace: Did any of the firms you worked for offer financial education programs, for example retirement seminars? i)Yes, ii) No, iii) Not applicable. As we show below, this enhanced set of questions provides new information not available in prior financial literacy surveys.

\section{Do People Plan for Retirement?}

As mentioned earlier, one of the difficulties of assessing the effects of financial literacy on behavior is that financial literacy may itself be the result of choice. Moreover, there are several channels through which financial literacy might affect interesting outcomes such as retirement saving. Rather than examining the effects of financial literacy on wealth or portfolio choice directly, in what follows, we focus on one specific but very important determinant of savings, namely retirement planning. As the model sketched above posits, consumers should be forward-looking and planning ahead for the future. Yet this simple model does not incorporate any difficulty or planning costs that people may face, particularly in the face of widespread financial illiteracy. The prediction of simple models that incorporate such costs is that people who are more financially literate are more efficient at devising retirement plans; in turn, lower planning costs enhance the likelihood of people planning for retirement. Accordingly, we examine whether financial literacy results in enhanced retirement planning.

To evaluate this outcome, we use the retirement planning measure we devised in the HRS, which is a strong predictor of wealth (Lusardi, 1999, 2003; Lusardi and Mitchell, 2007a; Lusardi and Beeler, 2007). The question wording is as follows: How much have you thought 
about retirement? A lot, some, little, or hardly at all ${ }^{11} \mathrm{~A}$ few papers have already assessed the relationships between retirement planning and financial literacy (Lusardi and Mitchell, 2006, 2007a, 2008), but they have not yet proved the direction of causality between financial literacy and retirement planning. In what follows, we use a more exogenous source of variation with regard to financial literacy than has been attempted in previous work, to get at this causality.

\section{Empirical Results}

Our evidence on basic and sophisticated financial literacy measures appears in Tables 1 and 2. The empirical analysis includes 989 observations taken from the ALP; summary statistics appear in Appendix Table 1. The average respondent age is 45; 60 percent of respondents are married and 48 percent are male; 29 percent of the sample has a high school or lower degree; and 16 percent are fully retired. ${ }^{12}$

It will be recalled that the basic financial literacy questions are intended to measure simple concepts crucial for everyday financial transactions and decision-making. Table 1 reports response patterns by question (Panels A and B) and by respondent socioeconomic characteristics (Panel C). The results show that ALP respondents can do simple calculations regarding interest rates and they also understand the effects of inflation. Yet almost a quarter of respondents cannot give the right answer to the compound interest question and the query regarding the time value of money. ${ }^{13}$ Similarly, a sizable fraction of respondents suffers from money illusion. Moreover, even though respondents can respond to individual questions accurately, fewer than half (44

\footnotetext{
${ }^{11}$ In the 2004 HRS module, we used different wording to elicit whether people plan for retirement. Specifically, we asked respondents whether they ever tried to figure out how much they need to save for retirement. These two planning measures display a strong positive correlation; despite its simplicity, the measure used in this paper does a better job of differentiating between different types of planners.

${ }^{12} \mathrm{~A}$ handful of observations with missing data on the demographic variables are deleted along with a few cases of multiple responses.
} 
percent) of the respondents can correctly answer all five questions (Panel B). In other words, in the ALP survey, basic financial concepts are not widely understood.

Panel C offers insight into which financial literacy patterns vary by age, educational attainment, and sex. Respondents age 50+ are consistently better informed, although the age differences are often not large. Differences in financial literacy by education are more striking: those with less than college are much more likely to respond incorrectly, especially to questions on compound interest, the time value of money, and inflation. It is also clear that women exhibit much lower levels of financial literacy than men, where sex differences are large for all but the money illusion question. These findings are similar to those in the older sample of the HRS (Lusardi and Mitchell, 2006, 2008), and international surveys as well (see OECD Report on Financial Literacy (2005) for an overview).

Responses to the new, more sophisticated financial literacy questions are summarized in Table 2. Panel A shows that most respondents (over three-quarters) get most of the answers right, so they do have some knowledge of how the stock market and risk diversification work. They are also more likely to be more knowledgeable about fluctuations in assets than about patterns of asset returns. But the question linking bond prices and interest rates proves very difficult: only one-third knows about this relationship. There is also a wide range of incorrect and don't know (DK) responses, with the DK's ranging from 6 to 25 percent depending on the question. Also of interest is the fact shown in Panel B that only 16 percent of respondents can answer all eight of these sophisticated questions accurately, confirming that sophisticated financial literacy is not widespread.

\footnotetext{
${ }^{13}$ Difficulties with interest compounding are similarly documented in other papers (Lusardi and Mitchell, 2007a; van Rooij, Lusardi and Alessie, 2007; Lusardi and Tufano, 2009).
} 
More detail on who can accurately answer the questions appears by socioeconomic group in Panel C. As with the basic financial literacy questions, younger respondents are less well informed than their older counterparts: for instance, 60 percent of the younger people versus 69 percent of the older ones know about mutual funds. The younger group is also 20 percentage points less likely to correctly judge that owning company stock is riskier than investing in an equity mutual fund. This corroborates our findings from another study, where we examined data from round 11 of the 1997 National Longitudinal Survey of Youth (NLSY97), which included the same three financial literacy questions used in the HRS. There we also found that financially illiteracy was widespread among young people (Lusardi, Mitchell and Curto, 2008). Once again, the better educated respondents are more knowledgeable than their less educated counterparts, with those having at least some college having much more accurate views of what the stock market does and the long run expected return advantage for stocks. Sex differences are sharp, in that women know substantially less than men with regard to mutual funds, risk diversification, long term returns, and the relationship between bond prices and interest rates. ${ }^{14}$

To establish whether respondents actually know the answers to our questions, we invert the order of three questions and results appear in Table 3. Responses to Q5 regarding the risk of bonds versus stocks are unaffected by which asset appears first in the question. This is an important result that shows that respondents generally understand the meaning of this question and hence are unlikely to be guessing in their responses. By contrast, a different pattern emerges for Q4, the more difficult query about company stock versus stock mutual funds. We previously piloted this wording in the 2004 HRS where it was asked over the telephone; in that instance, almost half of the older HRS respondents could not answer correctly or stated they did not know

\footnotetext{
${ }^{14}$ See also Lusardi and Mitchell (2008) for a discussion of financial literacy among women and Lusardi and Tufano (2009) for evidence of lower "debt literacy" among women.
} 
the answer. In the ALP, it is interesting that 74 percent of the Internet respondents get the answer right when the question is structured so that the correct answer is True, but 68 percent get it right when the correct answer is False. Thus there is confusion among respondents about this question. Answers to Q3, which is a complex question about bond pricing, are again affected by the wording: 46 percent get the answer wrong when the question asks what happens when interest rates fall, while 41 percent get it wrong when the interest rate is stipulated to rise. What this shows is that financial knowledge is likely measured with error; accordingly, empirical analysis of such patterns must take this into account. Below we deal with this issue in more detail.

To differentiate respondents' levels of financial knowledge, we next undertake factor analysis to construct a financial literacy index with the rich information obtained about basic and sophisticated financial literacy. Our initial analysis of the complete set of 13 questions pointed to two main factors with different loading on the basic versus the sophisticated financial literacy questions. Therefore we performed a separate factor analysis on the two types of queries separately, which permits us to construct two financial literacy indices: one related to basic knowledge, and a second measuring more advanced concepts. ${ }^{15}$

To show that these indices measure economic knowledge, Table 4 reports the relationship between these more objective financial literacy measures and the subjective indicator of financial knowledge in which people self-report their own understanding of economics on a scale from 1 to 7 (see Panels A and B). We note that this question appeared at the beginning of the financial literacy module, before any of the basic and advanced financial literacy questions were posed, so respondents' views were not contaminated by the financial literacy questions. Note that most

\footnotetext{
${ }^{15}$ Additional information regarding the factor analysis is provided in Appendix A.
} 
respondents chose high scores: that is 269 (out of 989) respondents grade themselves as a 4 out of 7; 343 assign themselves a level of 5; and 165 report their level is 6 (and 44 report their knowledge of economics is very high or 7 out of 7). Most importantly, there is a very strong correlation between objective and subjective financial literacy. That is, the majority of respondents who report they know a lot about economics (self-reporting a score of 6 or 7) also fall in the top two quartiles of the basic financial literacy index. The relationship becomes even stronger when we consider the advanced financial literacy index, where more than 50 percent of respondents who report low levels of economic knowledge (scoring 1, 2 or 3 ) fall in the lowest quartile of the financial literacy index, whereas the majority of those who report high knowledge fall in the top two quartiles of the financial literacy index. In sum, while there is some noise and measurement error affecting these indices, self-reports provide useful information about economic knowledge.

Next we seek to explore how knowledge is formed or developed by seeing how basic and sophisticated financial literacy compares between those who have and have not been exposed to financial literacy in high school and at work. As Panels C and D of Table 4 indicate, those exposed to financial education earlier in life have high levels of financial literacy during adulthood. Exposure to economics in school makes respondents more likely to locate in the top quartiles of sophisticated financial literacy. Furthermore, those exposed to financial education in the workplace are much less likely to fall in lower quartiles of the financial literacy index (Panels A and $B$ of Table 5). 


\section{Financial Literacy and Retirement Planning}

Ultimately we seek to answer not only whether respondents are financially literate, but also whether financial literacy matters in financial decision-making. To this end, we next assess whether financial literacy influences retirement planning, which has previously been found to be a powerful determinant of wealth (Lusardi and Mitchell, 2007a). Retirement planning is readily assessed by asking how much respondents have thought about retirement; results by socioeconomic characteristics appear in Table 6. The majority of ALP respondents (68 percent) reports having thought some or a lot about retirement. Moreover, older, better educated, and male respondents are more likely to be planners. These are also the characteristics of people who have a higher level of financial knowledge.

Next we turn to a multivariate analysis where we link retirement planning to financial literacy, holding constant other socioeconomic factors. Our objective is to assess whether financial literacy has an effect on planning, above and beyond the traditional determinants of planning considered in life-cycle models of saving, such as age and income (and several other demographics that can account for differences in preferences, such as sex, education, and marital status). Two models appear in Table 7 . The first is an ordinary linear multivariate regression (OLS; column 1), where the dependent variable takes the value of 1 if the respondent has thought "hardly at all about retirement", and it rises to a value of 4 for someone who has thought "a lot" about retirement. Here we see that financial knowledge is indeed influential in retirement planning, even after controlling for a range of socioeconomic factors. In other words, the index of financial literacy still has its own independent effect, above and beyond other determinants of planning. Even more telling is that sophisticated financial knowledge is the most important factor. We also note that both financial literacy and formal education are important: thus having 
an advanced degree boosts the probability of retirement planning even after controlling for financial literacy. ${ }^{16}$ This confirms HRS results in models which use a similar planning measure but include only the basic financial literacy questions (Lusardi and Mitchell, 2006). ${ }^{17}$

The second column in Table 7 is offered to explore the question of whether financial literacy is itself endogenous. That is, if those who attempted to plan for retirement became more financially knowledgeable, then planning could be said to influence financial literacy rather than the reverse. To evaluate this possibility, we have used a more exogenous source of variation in financial literacy as an instrument. Specifically, we note that, over the last several decades, several U.S. states have mandated high school financial education (mostly due to political rationales rather than to stimulate retirement planning; see Bernheim, Garrett, and Maki, 2001). ${ }^{18}$ Since the ALP reports the state in which respondents were born, we use it as a proxy for state residence at age 17 so we can infer whether the state in which the respondent lived at that time had mandated financial education.

Our model also adds additional interactions to take into account nonlinear exposure to this financial literacy training. For instance, exposure to such programs could contribute to the accumulation of knowledge later in life, so we interact the mandate dummy with age to discern whether the effect grows over the life cycle. To evaluate sex differences, we interact the mandate

\footnotetext{
${ }^{16}$ Some have argued that financial literacy measures are simply a proxy for cognitive ability. We address this problem by designing questions that test for "knowledge" rather than simply skills and IQ. One question that measures knowledge of finance is the one related to bond pricing, and in general, many of the sophisticated financial literacy questions cannot be answered correctly without some knowledge of economics and finance. In our estimate, it is the sophisticated financial literacy index that is statistically significant, and it seems unlikely that this indicator is merely proxying for cognition. Moreover, in studies where we can directly control for IQ/cognitive ability, we find that financial literacy effects remain statistically significant (Lusardi, Mitchell and Curto, 2008; van Rooij, Lusardi and Alessie, 2007).

${ }^{17}$ To the extent that our literacy questions are noisy measures, the OLS estimates may suffer from attenuation bias and therefore underestimate the full effects of financial literacy.

${ }^{18} \mathrm{Here}$, the instrumental variables strategy, which relies on state high school mandates to teach financial literacy implemented in different states and across different periods of time, also avoids the problem of proxying for cognitive ability. As a result we are confident that our estimates actually measure the effects of financial literacy rather than cognition or intelligence.
} 
dummy with sex to see whether requiring high school financial education has a differential impact for men versus women. Finally, we interact the dummy with educational expenses per pupil when the respondent was age 17 to account for the fact that some schools, while mandating financial education, may not have increased their budget to accommodate this new program. These additional variables are in keeping with Card and Krueger (1992) and Burtless (1996), who show that individuals who lived in states where higher amounts of resources were devoted to education do have better outcomes (for example, higher rates of return to education) later in life.

Estimates from the first stage regression in Table 8 highlight the importance of not only mandating financial education but also allocating resources to education. Financial knowledge is higher in those states that mandated education and spent more on education.

To focus attention on the sophisticated financial literacy measures developed for this paper, the instrumental variables (IV) estimation is performed on the advanced financial literacy index only. Results appear in Table 7, where we see that the instruments are statistically significant both individually and jointly. The estimates show that the impact of the financial literacy index in the planning equation is positive, statistically significant, and larger than the OLS estimate. Financial literacy not only matters for planning but its effect is sizable. Increasing the financial literacy index from values in the first quartile to values in the third quartile would move the respondent up one level in the retirement planning scale (i.e., if the respondent was planning for retirement "hardly at all", it would now plan "a little" for retirement). Given the relationship between retirement planning and wealth, this also means that higher financial literacy would lead to higher wealth accumulation. Consequently, we conclude that financial literacy does influence retirement planning, and that exogenous variation in financial literacy is 
needed to disentangle the causal relationships of interest between consumer financial decisionmaking and the building of financial human capital.

\section{Alternative Empirical Specifications and Robustness Checks}

We have also explored alternative specifications to help assess the robustness of our findings. For instance, as we noted earlier, there appears to be some measurement error in answers provided to the sophisticated financial literacy questions, since responses to the questions where wording was randomized suggest some evidence of guessing. Accordingly, Panel A of Table 9 excludes from the financial literacy index the three questions that we randomized, to help examine the sensitivity of our estimates to the type of questions included in the financial literacy index. In particular, these results exclude the most difficult question about bond pricing, which means that the new financial literacy index is restricted to simpler knowledge levels. We have used the same set of controls as in Table 7 (for brevity, estimates of the controls are not reported). The coefficient of this alternative index of financial literacy is again positive and statistically significant.

Two additional robustness checks split the sample by age and retirement status, in order to focus attention on respondents who are likely to be most actively planning ahead for retirement. Accordingly, Panel B excludes those older than 62 and Panel C excludes respondents who report themselves as fully retired. Restricting the sample to the younger age group may permit the instruments to have stronger predictive power, since economic training acquired in high school may become obsolete over time. The importance of financial literacy remains strong in these alternative specifications, and the magnitudes of the IV coefficient estimate remain 
positive and statistically significant as before. In sum, we conclude that more financially knowledgeable younger and non-retired respondents are also more likely to plan for retirement.

\section{Conclusion and Discussion}

Policymakers are beginning to acknowledge the central importance of financial literacy for a well-functioning economy: for instance, Roger Ferguson (2002), as Federal Reserve Board Vice Chairman, noted that "when millions of educated consumers make good personal financial choices, our economy is strengthened in fundamental ways." Nowhere is this more true than in the retirement preparedness arena. Yet planning for retirement is a complex undertaking, requiring the consumer to gather and process data on compound interest, risk diversification, and inflation, and make assumptions about future asset market performance. This paper contributes to the literature on what consumers know and how their financial literacy capital drives their retirement planning and saving patterns.

The present research using the ALP extends prior analysis using the HRS by Lusardi and Mitchell $(2006,2007 \mathrm{a})$ inasmuch as the earlier work used much simpler financial literacy questions. By contrast, here we explore several additional dimensions of the financial literacy picture. Furthermore, we create a financial literacy index and correct for possible endogeneity using some sensible instruments. By every measure, and in every sample we have examined, we conclude that financial literacy is a key determinant of retirement planning. We also find that respondent financial literacy is higher when consumers have been exposed to economics in school and in employer-sponsored programs. ${ }^{19}$

\footnotetext{
${ }^{19}$ Our work extends the findings derived using more specialized samples by Bernheim, Garrett and Maki (2001) and Bernheim and Garrett (2003).
} 
This research should be of interest to educators and employers seeking to enhance efforts to plan and save for retirement, as well as researchers interested in exploring financial literacy further. In the future, it will be critical to ask specific questions about financial knowledge as outlined here, since education, income, and age are correlated with but do not adequately capture all the dimensions of respondents' financial literacy human capital. Additionally, the fact that we find more financially literate adults to be more likely to plan for retirement complements work by other analysts seeking to link financial sophistication and decision-making. For instance, some evidence points to the fact that financially unsophisticated households tend to avoid the stock market (van Rooij, Lusardi and Alessie, 2007; Kimball and Shumway, 2006; Christelis, Jappelli and Padula, 2006), and are less likely to choose mutual funds with lower fees (Hastings and Tejeda-Ashton, 2008). The financially unsophisticated are also less likely to refinance their mortgages in a propitious environment (Campbell, 2006), and they select less advantageous mortgages in the first place (Moore, 2003). People who cannot correctly calculate interest rates given a stream of payments tend to borrow more and accumulate less wealth (Stango and Zinman, 2008). Now our results show that the financially illiterate do not plan for retirement either.

We are cognizant of the fact that promoting financial literacy is a difficult and likely costly task, and more research is required to determine when and how to most efficiently invest in consumer financial literacy. It is also clear that it is necessary to enhance financial knowledge if consumers are to do a better job navigating the complexities of the modern financial environment. Indeed, very young adults receive multiple credit cards, they may take out loans, and they can readily purchase assets ranging from mutual funds to stocks and tax-favored plans such as IRAs and 401(k)s. However, our work shows that young adults are not well equipped to 
make financial decisions (Lusardi, Mitchell and Curto, 2008). Saving for retirement is becoming more challenging but also more critical for younger consumers, requiring ever-greater levels of financial sophistication. It is thus urgent to develop, evaluate, and target effective programs to those who can put this necessary financial knowledge to work. 


\section{References}

Agnew, J., and L. Szykman. 2005. "Asset allocation and information overload: The influence of information display, asset choice and investor experience." Journal of Behavioral Finance, 6, 57-70.

Agarwal, S., J. Driscoll, X. Gabaix, and D. Laibson. 2007. "The age of reason: Financial decisions over the lifecycle." NBER Working Paper n. 13191.

Ameriks, J., A. Caplin and J. Leahy. 2003. "Wealth Accumulation and the Propensity to Plan." Quarterly Journal of Economics, 68, 1007-1047.

Bartlett, M., 1937. "The statistical conception of mental factors." British Journal of Psychology, 28, 97-104.

Bayer, P., D. Bernheim, and J. K. Scholz. 1996. "The Effects of Financial Education in the Workplace: Evidence from a Survey of Employers." NBER Working Paper n. 5655.

Bernheim, D. 1995. "Do households appreciate their financial vulnerabilities? An analysis of actions, perceptions, and public policy." In: Tax Policy and Economic Growth, American Council for Capital Formation, Washington, D.C.

Bernheim, D. 1998. "Financial illiteracy, education and retirement saving." In: O. S. Mitchell and S. Schieber (eds.), Living with Defined Contribution Pensions, University of Pennsylvania Press, Philadelphia.

Bernheim, D., D. Garrett, and D. Maki. 2001. "Education and saving: The long-term effects of high school financial curriculum mandates.” Journal of Public Economics, 85, 435-565.

Bernheim, D., and D. Garrett. 2003. "The effects of financial education in the workplace: Evidence from a survey of households.” Journal of Public Economics, 87, 1487-1519.

Bucks, B., and K. Pence. 2008. "Do Borrowers Know Their Mortgage Terms?” Journal of Urban Economics, 64, 218-33.

Burtless, G. 1996. Does Money Matter? The Effect of School Resources on Student Achievement and Adult Success. Washington, D.C.: Brookings Foundation Press.

Campbell, J. 2006. “Household finance.” Journal of Finance, 61, 1553-1604.

Card, D. and A. Krueger. 1992. "Does School Quality Matter? Returns to Education and the Characteristics of Public Schools in the United States." Journal of Political Economy, 100, 1-40.

Christelis, D., T. Jappelli, and M. Padula. 2006. "Cognitive abilities and portfolio choice."” CSEF Working Paper 157, University of Salerno.

Duflo, E. and E. Saez. 2004. "Implications of Pension Plan Features, Information, and Social Interactions for Retirement Saving Decisions.” In: O. S. Mitchell and S. Utkus (eds.), Pension 
Design and Structure: New Lessons from Behavioral Finance, Oxford: Oxford University Press, 137-153.

Ferguson, R. 2002. "Reflections on Financial Literacy." Remarks before the National Council on Economic Education, Washington, D.C. May 13.

Gustman, A., T. Steinmeier, and N. Tabatabai. 2008. "Do Workers Know about Their Pension Plan Type? Comparing Workers' and Employers' Pension Information.” In: A. Lusardi (ed.), Overcoming the Saving Slump: How to Increase the Effectiveness of Financial Education and Saving Programs, Chicago: University of Chicago Press, 47-81.

Gustman, A. and T. Steinmeier. 2004. "What People Don't Know about their Pensions and Social Security." In: William Gale, John Shoven and Mark Warshawsky (eds.), Private Pensions and Public Policies, Washington, D.C.: Brookings Institution, 57-125.

Hastings, J. and L. Tejeda-Ashton. 2008. "Financial Literacy, Information, and Demand Elasticity: Survey and Experimental Evidence from Mexico." NBER Working Paper n. 14538.

Hilgert, M., J. Hogarth, and S. Beverly. 2003. "Household financial management: The connection between knowledge and behavior." Federal Reserve Bulletin, 309-322.

Hurst, E. 2006. "Grasshoppers, Ants and Pre-Retirement Wealth: A Test of Permanent Income Consumers." Working paper, University of Chicago Graduate School of Business.

Kimball, M. and T. Shumway. 2006. "Investor Sophistication, and the Participation, Home Bias, Diversification, and Employer Stock Puzzles." Mimeo, University of Michigan.

Lusardi, A. 1999. "Information, Expectations, and Savings for Retirement." In: Henry Aaron (ed.), Behavioral Dimensions of Retirement Economics, Washington, D.C.: Brookings Institution and Russell Sage Foundation, 81-115.

Lusardi, A. 2002. "Preparing for Retirement: The Importance of Planning Costs." National Tax Association Proceedings - 2002, 148-154.

Lusardi, A. 2003. "Planning and Saving for Retirement." Working Paper, Dartmouth College. http://www.dartmouth.edu/ alusardi/Papers/Lusardi_pdf.pdf.

Lusardi, A. 2004. "Saving and the Effectiveness of Financial Education." in O. Mitchell and S. Utkus (eds.), Pension Design and Structure. New Lessons from Behavioral Finance, New York: Oxford University press, pp. 157-184.

Lusardi, A. 2008. "Household Saving Behavior: The Role of Literacy, Information and Financial Education Programs." NBER Working Paper n. 13824.

Lusardi, A. and J. Beeler. 2007. "Saving Between Cohorts: The Role of Planning." In Brigitte Madrian, Olivia Mitchell, and Beth Soldo (eds.), Redefining Retirement: How Will Boomers 
Fare? Oxford: Oxford University Press.

Lusardi, A., and O. S. Mitchell. 2006. "Financial literacy and planning: Implications for retirement wellbeing." Pension Research Council Working Paper 1, The Wharton School.

Lusardi, A., and O. S. Mitchell. 2007a. "Baby boomers retirement security: The role of planning, financial literacy and housing wealth." Journal of Monetary Economics, 54, 205-224.

Lusardi, A., and O. S. Mitchell. 2007b. "Financial literacy and retirement preparedness: Evidence and implications for financial education." Business Economics, 35-44.

Lusardi, A. and O. S. Mitchell. 2008. "Planning and Financial Literacy. How Do Women Fare?" American Economic Review, 98(2), 413-417.

Lusardi, A., O. S. Mitchell, and V. Curto. 2008. "Financial Literacy among the Young: Evidence and Implications for Consumers Policy." Mimeo, Dartmouth College.

Lusardi, A. and P. Tufano. 2009. "Debt Literacy, Financial Experiences, and Overindebtedness." NBER Working Paper n. 14808.

Mandell, L. 2008. "Financial Education in High School.” In: Annamaria Lusardi (ed.), Overcoming the Saving Slump: How to Increase the Effectiveness of Financial Education and Saving Programs, Chicago: University of Chicago Press, 257-279.

Mishkin, F. 2008. "The Importance of Economic Education and Financial Literacy." Speech before the Federal Reserve Board at the Third National Summit on Economic and Financial Literacy, Washington, D.C. February 27.

Mitchell, O. S. 1988. "Worker Knowledge of Pension Provisions." Journal of Labor Economics 6, January: 21-39.

Moore, D. 2003. "Survey of financial literacy in Washington State: Knowledge, behavior, attitudes and experiences." Technical report 03-39, Social and Economic Sciences Research Center, Washington State University.

National Council on Economic Education. 2005. "What American teens and adults know about economics." Monograph, Washington, D.C.

Organization for Economic Co-Operation and Development. 2005. Improving Financial Literacy: Analysis of Issues and Policies, Paris, France.

Stango, V. and J. Zinman. 2008. "Exponential Growth Bias and Household Finance.” Working Paper, Dartmouth College.

Van Rooij, M., A. Lusardi and R. Alessie. 2007. "Financial Literacy and Stock Market Participation." NBER Working Paper n. 13565. 
Table 1. Descriptive Results for Basic Financial Literacy Questions ( \% of respondents)

A. Percent Correct by Basic Financial Literacy Question

\begin{tabular}{lrrrrr} 
& Numeracy & $\begin{array}{r}\text { Compound } \\
\text { interest }\end{array}$ & Time value of & $\begin{array}{r}\text { Money } \\
\text { Intlasion }\end{array}$ \\
\hline Correct & 91.8 & 69.0 & 87.1 & 73.8 & 78.4 \\
Incorrect & 6.8 & 29.1 & 8.8 & 19.6 & 20.3 \\
DK & 1.0 & 1.9 & 4.1 & 6.6 & 1.2 \\
Refusal & 0.4 & 0.0 & 0.1 & 0.0 & 0.1 \\
\hline
\end{tabular}

B. Percent Correct: Summary of Responses to All Basic Financial Literacy Questions (5 questions total)

Number of Correct, Incorrect and DK answers

\begin{tabular}{|c|c|c|c|c|c|c|c|}
\hline & None & One & Two & Three & Four & All Five & $\begin{array}{r}\text { Mean \# of } \\
\text { answers } \\
\end{array}$ \\
\hline Correct & 1.8 & 1.2 & 7.3 & 18.2 & 27.7 & 43.8 & 4.0 \\
\hline Incorrect & 47.5 & 28.5 & 18.1 & 4.2 & 1.0 & 0.6 & 0.8 \\
\hline DK & 87.5 & 10.9 & 1.0 & 0.7 & 0.0 & 0.0 & 0.1 \\
\hline Refusal & 99.5 & 0.5 & 0.0 & 0.0 & 0.0 & 0.0 & 0.0 \\
\hline
\end{tabular}

C. Percent Correct by Basic Financial Literacy Question and Socioeconomic Characteristics

\begin{tabular}{|c|c|c|c|c|c|}
\hline & Numeracy & $\begin{array}{r}\text { Compound } \\
\text { interest }\end{array}$ & Inflation & $\begin{array}{r}\text { Time value of } \\
\text { money }\end{array}$ & Money illusion \\
\hline \multicolumn{6}{|c|}{ Age $>50(N=546)$} \\
\hline Correct & 92.9 & 74.2 & 91.2 & 75.8 & 78.2 \\
\hline Incorrect & 6.5 & 23.6 & 5.4 & 20.3 & 20.3 \\
\hline DK & 0.6 & 2.2 & 3.3 & 3.8 & 1.3 \\
\hline Refusal & 0.0 & 0.0 & 0.2 & 0.1 & 0.2 \\
\hline \multicolumn{6}{|c|}{$\operatorname{Age} \leq \mathbf{5 0}(\mathrm{N}=443)$} \\
\hline Correct & 91.3 & 66.2 & 84.9 & 72.7 & 78.5 \\
\hline Incorrect & 6.9 & 32.1 & 10.6 & 19.2 & 20.3 \\
\hline DK & 1.2 & 1.7 & 4.6 & 8.1 & 1.2 \\
\hline Refusal & 0.6 & 0.0 & 0.0 & 0.0 & 0.0 \\
\hline \multicolumn{6}{|c|}{ Education: College or more $(\mathrm{N}=526)$} \\
\hline Correct & 96.8 & 77.5 & 90.7 & 78.8 & 84.0 \\
\hline Incorrect & 3.0 & 22.1 & 8.0 & 12.4 & 14.3 \\
\hline DK & 0.2 & 0.4 & 1.1 & 8.7 & 1.6 \\
\hline Refusal & 0.0 & 0.0 & 0.1 & 0.1 & 0.1 \\
\hline \multicolumn{6}{|c|}{ Education: Less than College $(\mathrm{N}=463)$} \\
\hline Correct & 87.8 & 62.0 & 84.0 & 69.7 & 73.7 \\
\hline Incorrect & 9.9 & 34.9 & 9.4 & 25.5 & 25.3 \\
\hline DK & 1.6 & 3.1 & 6.6 & 4.8 & 1.0 \\
\hline Refusal & 0.7 & 0.0 & 0.0 & 0.0 & 0.0 \\
\hline \multicolumn{6}{|c|}{ Male $(\mathrm{N}=444)$} \\
\hline Correct & 95.2 & 81.3 & 91.0 & 85.8 & 79.0 \\
\hline Incorrect & 3.7 & 17.4 & 5.8 & 9.7 & 20.0 \\
\hline DK & 0.2 & 1.3 & 3.1 & 4.5 & 0.9 \\
\hline Refusal & 0.8 & 0.0 & 0.1 & 0.0 & 0.1 \\
\hline \multicolumn{6}{|c|}{ Female $(N=545)$} \\
\hline Correct & 88.8 & 57.9 & 83.5 & 63.0 & 77.9 \\
\hline Incorrect & 9.5 & 39.8 & 11.4 & 28.5 & 20.5 \\
\hline DK & 1.7 & 2.3 & 5.0 & 8.5 & 1.5 \\
\hline Refusal & 0.0 & 0.0 & 0.0 & 0.0 & 0.0 \\
\hline
\end{tabular}

Note: $\mathrm{N}$ obs=989; weighted sample. 
Table 2. Descriptive Results for Sophisticated Financial Literacy Questions (\% of respondents)

\section{A. Percent Correct by Basic Financial Literacy Question}

\begin{tabular}{|c|c|c|c|c|}
\hline & Correct & Incorrect & $D K$ & Refusal \\
\hline Q1. Main function of the stock market & 71.5 & 20.2 & 8.3 & 0.0 \\
\hline Q2. Knowledge of mutual fund. & 63.0 & 13.6 & 23.3 & 0.0 \\
\hline Q3. Relation between interest rate and bond prices ${ }^{\mathrm{b}}$ & 31.6 & 43.8 & 24.5 & 0.1 \\
\hline Q4. What is safer: company stock vs stock mutual fund ${ }^{\mathrm{b}}$ & 71.4 & 4.0 & 24.5 & 0.0 \\
\hline Q5. Which is riskier: stocks vs bonds ${ }^{\mathrm{b}}$ & 80.2 & 5.4 & 14.4 & 0.1 \\
\hline $\begin{array}{l}\text { Q6. Highest return over long period: savings accounts, bonds } \\
\text { or stocks }\end{array}$ & 62.3 & 27.5 & 10.1 & 0.1 \\
\hline Q7. Highest fluctuations: savings accounts, bonds, stocks & 88.3 & 4.5 & 7.1 & 0.0 \\
\hline Q8. Risk diversification & 74.9 & 18.4 & 6.7 & 0.1 \\
\hline
\end{tabular}

B. Percent Correct: Summary of Responses to Sophisticated Financial Literacy Questions (8 questions total)

Number of Correct, Incorrect and DK answers

\begin{tabular}{lrrrrrrrrrr} 
& None & One & Two & Three & Four & Five & Six & Seven & All 8 & $\begin{array}{r}\text { Mean \# of } \\
\text { answers }\end{array}$ \\
\hline Correct & 0.6 & 3.0 & 6.2 & 11.0 & 10.2 & 15.4 & 14.6 & 22.6 & 16.5 & 5.4 \\
Incorrect & 30.2 & 33.0 & 18.1 & 10.7 & 5.2 & 1.7 & 1.2 & 0.0 & 0.0 & 1.4 \\
DK & 50.0 & 18.5 & 12.3 & 9.1 & 6.1 & 2.0 & 0.4 & 1.2 & 0.4 & 1.2 \\
Refusal & 99.8 & 0.2 & 0.0 & 0.0 & 0.0 & 0.0 & 0.0 & 0.0 & 0.0 & 0.0 \\
\hline
\end{tabular}

C. Percent Correct by Sophisticated Financial Literacy Question and Socioeconomic Characteristics

\begin{tabular}{|c|c|c|c|c|c|c|c|c|}
\hline & Q1 & Q2 & Q3 & Q4 & Q5 & Q6 & Q7 & Q8 \\
\hline \multicolumn{9}{|c|}{ Age $>50(\mathrm{~N}=546)$} \\
\hline Correct & 74.0 & 68.6 & 31.8 & 84.0 & 79.9 & 61.5 & 87.8 & 79.3 \\
\hline Incorrect & 17.4 & 13.4 & 47.2 & 2.5 & 6.3 & 27.3 & 3.7 & 14.9 \\
\hline DK & 8.5 & 17.9 & 20.8 & 13.4 & 13.5 & 11.0 & 8.4 & 5.7 \\
\hline Refusal & 0.1 & 0.1 & 0.2 & 0.1 & 0.3 & 0.2 & 0.1 & 0.1 \\
\hline \multicolumn{9}{|c|}{ Age $<\mathbf{5 0}(\mathrm{N}=443)$} \\
\hline Correct & 70.2 & 60.0 & 31.5 & 64.7 & 80.3 & 62.8 & 88.5 & 72.5 \\
\hline Incorrect & 21.7 & 13.7 & 42.1 & 4.8 & 4.9 & 27.6 & 5.0 & 20.3 \\
\hline DK & 8.1 & 26.3 & 26.5 & 30.5 & 14.8 & 9.6 & 6.5 & 7.2 \\
\hline Refusal & 0.0 & 0.0 & 0.0 & 0.0 & 0.0 & 0.0 & 0.0 & 0.1 \\
\hline \multicolumn{9}{|c|}{ Education College $+(\mathrm{N}=526)$} \\
\hline Correct & 80.4 & 76.0 & 44.4 & 81.1 & 88.4 & 76.3 & 94.5 & 85.7 \\
\hline Incorrect & 16.6 & 8.9 & 31.0 & 2.9 & 3.9 & 15.4 & 2.4 & 12.3 \\
\hline DK & 2.9 & 15.0 & 24.4 & 15.9 & 7.6 & 8.2 & 3.0 & 2.0 \\
\hline Refusal & 0.1 & 0.1 & 0.2 & 0.1 & 0.1 & 0.1 & 0.1 & 0.1 \\
\hline \multicolumn{9}{|c|}{ Education $<$ College $(\mathrm{N}=463)$} \\
\hline Correct & 64.2 & 52.2 & 20.9 & 63.4 & 73.4 & 50.7 & 83.1 & 65.9 \\
\hline Incorrect & 23.1 & 17.5 & 54.5 & 4.9 & 6.6 & 37.6 & 6.3 & 23.5 \\
\hline DK & 12.7 & 30.3 & 24.6 & 31.7 & 20.0 & 11.7 & 10.5 & 10.6 \\
\hline Refusal & 0.0 & 0.0 & 0.0 & 0.0 & 0.1 & 0.1 & 0.0 & 0.1 \\
\hline \multicolumn{9}{|c|}{ Male $(\mathrm{N}=444)$} \\
\hline Correct & 79.7 & 76.0 & 45.4 & 83.1 & 82.3 & 78.5 & 90.9 & 81.3 \\
\hline Incorrect & 17.1 & 10.0 & 41.2 & 2.9 & 6.2 & 17.1 & 4.9 & 15.1 \\
\hline DK & 3.1 & 13.9 & 13.3 & 13.9 & 11.4 & 4.3 & 4.2 & 3.4 \\
\hline Refusal & 0.1 & 0.1 & 0.1 & 0.1 & 0.1 & 0.1 & 0.1 & 0.1 \\
\hline \multicolumn{9}{|c|}{ Female $(\mathrm{N}=545)$} \\
\hline Correct & 64.1 & 51.2 & 19.1 & 60.9 & 78.2 & 47.7 & 85.9 & 69.0 \\
\hline Incorrect & 22.9 & 16.9 & 46.3 & 4.9 & 4.7 & 37.0 & 4.2 & 21.4 \\
\hline DK & 12.9 & 31.9 & 34.7 & 34.2 & 17.0 & 15.4 & 9.9 & 9.6 \\
\hline Refusal & 0.0 & 0.0 & 0.0 & 0.0 & 0.1 & 0.0 & 0.0 & 0.0 \\
\hline
\end{tabular}

Note: $\mathrm{N}$ obs $=989$; weighted sample. 
Table 3. Percent Correct for Specific Sophisticated Financial Literacy Questions: Impact of Reverse Wording ( $\%$ of respondents)

Correct Incorrect DK Refusal

Q5:

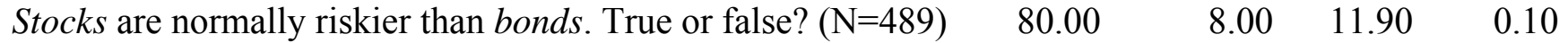

$\begin{array}{lllll}\text { Bonds are normally riskier than stocks. True or false? }(\mathrm{N}=500) & 80.30 & 2.10 & 17.50 & 0.10\end{array}$

Pearson chi2(3) $=21.1499(p=.00009799)$

Q4:

Buying a company stock usually provides a safer return than a stock mutual fund. True or false? $(\mathrm{N}=497)$

Buying a stock mutual fund usually provides a safer return than a company stock. True or false? $(\mathrm{N}=492)$

Pearson chi2 $(3)=5.9377(p=.11468091)$

$\begin{array}{llll}68.40 & 5.00 \quad 26.50 & 0.10\end{array}$

$\begin{array}{llll}74.50 & 2.90 \quad 22.60 & 0.00\end{array}$

Q3:

If the interest rate falls, what should happen to bond prices: rise/fall/stay the same/none of the above? $(\mathrm{N}=491)$

If the interest rate rises, what should happen to bond prices: rise/fall/stay the same/none of the above? $(\mathrm{N}=498)$

$\begin{array}{llll}30.80 & 46.30 \quad 23.00 & 0.00\end{array}$

Pearson chi2(3) $=3.1983(p=.36205004)$

$\begin{array}{llll}32.40 & 41.40 \quad 26.10 & 0.10\end{array}$


Table 4. Financial Literacy Indices, Self-assessed Financial Literacy, and School Economic Education

A. Basic Financial Literacy Index Compared to Self-assessed Financial Literacy (row percentages shown)

Financial Literacy Index Quartiles (\%) $3 \& 4$

\begin{tabular}{c|rrrr} 
Self-assessed financial literacy & 1 (Low) & 2 & $($ Top $)$ & $N$ \\
\hline 1 (very low) & 67.2 & 9.3 & 23.5 & 10 \\
2 & 65.3 & 27.4 & 7.4 & 43 \\
3 & 57.1 & 10.2 & 32.8 & 115 \\
4 & 40.4 & 26.0 & 33.6 & 269 \\
5 & 25.3 & 19.1 & 55.5 & 343 \\
6 & 29.6 & 21.8 & 48.6 & 165 \\
7 (very high) & 25.0 & 3.8 & 71.2 & 44 \\
\hline
\end{tabular}

B. Advanced Financial Literacy Index Compared to Self-assessed Financial Literacy (row percentages shown)

\begin{tabular}{c|r|rrrr} 
& \multicolumn{5}{c}{ Financial Literacy Index Quartiles () } \\
Self-assessed financial literacy & 1 (Low) & 2 & 3 & 4 (Top) & $N$ \\
\hline 1 (very low) & 75.6 & 19.1 & 5.3 & 0.0 & 10 \\
2 & 56.2 & 29.7 & 12.5 & 1.6 & 43 \\
3 & 53.4 & 24.6 & 18.9 & 3.1 & 115 \\
4 & 50.4 & 21.0 & 22.7 & 6.0 & 269 \\
5 & 27.1 & 22.4 & 29.0 & 21.6 & 343 \\
6 & 18.2 & 20.3 & 35.8 & 25.7 & 165 \\
7 (very high) & 29.1 & 4.6 & 13.6 & 52.7 & 44 \\
\hline
\end{tabular}

C. Basic Financial Literacy Index and School Economic Education (row percentages shown)

\begin{tabular}{|c|c|c|c|c|}
\hline \multirow[b]{2}{*}{ School Economic Education } & \multicolumn{4}{|c|}{ Financial Literacy Index Quartiles (\%) } \\
\hline & 1 & 2 & $3 \& 4$ & $N$ \\
\hline A lot of econ education & 9.50 & 39.10 & 51.41 & 50 \\
\hline Some econ education & 35.97 & 20.03 & 43.99 & 346 \\
\hline Little econ education & 34.21 & 20.04 & 45.75 & 397 \\
\hline No econ education & 47.45 & 14.63 & 37.92 & 196 \\
\hline
\end{tabular}

D. Advanced Financial Literacy Index and School Economic Education (row percentages shown)

Financial Literacy Index Quartiles (\%)

\begin{tabular}{lrrrrrr} 
School Economic Education & 1 (Low) & 2 & \multicolumn{2}{r}{4 (Top) } & $N$ \\
\hline A lot of econ education & 5.41 & 34.69 & 16.91 & 42.98 & 50 \\
Some econ education & 38.45 & 18.56 & 27.82 & 15.17 & 346 \\
Little econ education & 35.99 & 19.59 & 23.62 & 20.80 & 397 \\
No econ education & 45.89 & 26.60 & 21.89 & 5.62 & 196 \\
\hline
\end{tabular}


Table 5. Financial Literacy Indices and Firm Financial Education

A. Basic Financial Literacy Index and Firm Financial Education (row percentages shown)

Financial Literacy Index Quartiles (\%) $3 \& 4$

Firm Financial Education

No

1 (Low) 42.73

27.22

\begin{tabular}{rrr}
2 & (Top) & $N$ \\
\hline 14.72 & 42.55 & 524 \\
\cline { 2 - 3 } 27.14 & 45.64 & 465 \\
\hline
\end{tabular}

B. Advanced Financial Literacy Index and Firm Financial Education (row percentages shown)

Financial Literacy Index Quartiles (\%)

Firm Financial Education

No

Yes 1 (Low) 46.34 24.66

19.90

\begin{tabular}{rrr}
3 & 4 (Top) & $N$ \\
\hline 20.84 & 11.07 & 524 \\
\cline { 2 - 2 } 30.51 & 24.93 & 465 \\
\hline
\end{tabular}

Table 6. Patterns of Retirement Planning By Socioeconomic Characteristics (\%)

Age $\quad \underline{\text { Education }} \quad \underline{\text { Sex }}$ College Less than Full sample $>50 \quad 550$ or more college Male Female

How much have you thought about retirement?

\begin{tabular}{|c|c|c|c|c|c|c|c|}
\hline A lot & 26.5 & 42.4 & 17.9 & 25.9 & 26.9 & 25.6 & 27.3 \\
\hline Some & 43.0 & 41.0 & 44.0 & 49.1 & 37.9 & 47.2 & 39.1 \\
\hline A little & 16.6 & 12.1 & 19.0 & 8.3 & 23.5 & 13.3 & 19.7 \\
\hline Hardly at all & 14.0 & 4.5 & 19.0 & 16.7 & 11.7 & 14.0 & 13.9 \\
\hline
\end{tabular}


Table 7. Multivariate Ordinary Least Squares (OLS) and Instrumental Variable (IV) Analysis of Retirement Planning

\begin{tabular}{|c|c|c|}
\hline & OLS & IV \\
\hline \multirow[t]{2}{*}{ Advanced Financial Literacy Index } & 0.163 & 0.493 \\
\hline & {$[0.062]^{* * *}$} & {$[0.116]^{*}$} \\
\hline \multirow[t]{2}{*}{ Basic Financial Literacy Index } & -0.093 & -0.207 \\
\hline & {$[0.055]^{*}$} & {$[0.286]^{*}$} \\
\hline \multirow[t]{2}{*}{ Age } & 0.023 & 0.021 \\
\hline & {$[0.004]^{* * *}$} & {$[0.006]^{* * *}$} \\
\hline \multirow[t]{2}{*}{ Male } & -0.081 & -0.176 \\
\hline & [0.098] & [0.147] \\
\hline \multirow[t]{2}{*}{ Black } & -0.02 & 0.019 \\
\hline & {$[0.166]$} & [0.211] \\
\hline \multirow[t]{2}{*}{ Hispanic } & 0.239 & 0.204 \\
\hline & {$[0.169]$} & [0.253] \\
\hline \multirow[t]{2}{*}{ Married/partner } & -0.094 & -0.022 \\
\hline & {$[0.135]$} & [0.146] \\
\hline \multirow[t]{2}{*}{ Separated } & 0.255 & 0.279 \\
\hline & {$[0.446]$} & [0.472] \\
\hline \multirow{2}{*}{ Divorced } & 0.117 & 0.125 \\
\hline & {$[0.146]$} & [0.155] \\
\hline \multirow[t]{2}{*}{ Widowed } & 0.061 & 0.21 \\
\hline & {$[0.246]$} & [0.274] \\
\hline \multirow[t]{2}{*}{ Some college } & 0.197 & 0.088 \\
\hline & [0.127] & [0.169] \\
\hline \multirow[t]{2}{*}{ Associate degree } & 0.261 & 0.084 \\
\hline & {$[0.147]^{*}$} & [0.228] \\
\hline \multirow[t]{2}{*}{ College degree } & 0.052 & -0.125 \\
\hline & [0.149] & [0.242] \\
\hline \multirow{2}{*}{ Masters degree } & 0.095 & -0.021 \\
\hline & {$[0.157]$} & [0.244] \\
\hline \multirow[t]{2}{*}{ Doctorate degree } & 0.196 & -0.011 \\
\hline & {$[0.166]$} & [0.259] \\
\hline \multirow[t]{2}{*}{ Income $\$ 25,000-49,999$} & 0.653 & 0.515 \\
\hline & {$[0.163]^{* * *}$} & {$[0.184]^{* * *}$} \\
\hline \multirow[t]{2}{*}{ Income $\$ 50,000-74,999$} & 0.831 & 0.682 \\
\hline & {$[0.182]^{* * *}$} & {$[0.195]^{* * *}$} \\
\hline \multirow[t]{2}{*}{ Income $\$ 75,000-99,999$} & 0.88 & 0.707 \\
\hline & {$[0.180]^{* * *}$} & {$[0.208]^{* * *}$} \\
\hline \multirow[t]{2}{*}{ Income $\$ 100,000-149,999$} & 1.005 & 0.815 \\
\hline & {$[0.179]^{* * *}$} & {$[0.213]^{* * *}$} \\
\hline \multirow[t]{2}{*}{ Income $\geq \$ 150,000$} & 1.123 & 0.884 \\
\hline & {$[0.210]^{* * *}$} & {$[0.245]^{* * *}$} \\
\hline \multirow[t]{2}{*}{ Unemployed } & 0.473 & 0.417 \\
\hline & {$[0.200]^{* *}$} & {$[0.232]^{*}$} \\
\hline Disabled & 0.111 & 0.069 \\
\hline & {$[0.302]$} & {$[0.324]$} \\
\hline Retired & -0.002 & -0.064 \\
\hline & {$[0.144]$} & [0.159] \\
\hline Homemaker & 0.05 & -0.013 \\
\hline & [0.169] & [0.192] \\
\hline $\mathrm{N}$ obs & 989 & 936 \\
\hline R-squared & 0.37 & \\
\hline Hansen $\mathrm{J}$ test $\mathrm{p}$-value & & 0.0404 \\
\hline F-statistic first stage regression & & 4.12 \\
\hline
\end{tabular}

Note: Robust standard errors in brackets; ${ }^{* * *} \mathrm{p}<0.01,{ }^{* *} \mathrm{p}<0.05,{ }^{*} \mathrm{p}<0.1$. Control for missing income also included. 
Table 8: First Stage Regression

Coefficient estimate

Financial Education Mandate

$[0.646]^{* * *}$

Age*Education Mandate

0.031

Male*Education Mandate

$[0.011]^{* * *}$

$-0.618$

Expenditure per Pupil*Education Mandate

$[0.199]^{* * *}$

0.024

Basic Financial Literacy Index

$[0.008]^{* * *}$

0.379

$[0.047]^{* * *}$

Age

0.01

Male

$[0.004]^{* *}$

0.513

$[0.085]^{* * *}$

Black

$-0.216$

[0.173]

Hispanic

$-0.32$

[0.189]*

Married/partner

$-0.107$

[0.112]

Separated

0.04

[0.236]

0.091

Divorced

[0.141]

Widowed

$-0.094$

[0.211]

Some college

0.296

[0.117]**

Associate degree

0.543

$[0.145]^{* * *}$

College degree

0.653

Masters degree

[0.118]***

0.637

$[0.130]^{* * *}$

Doctorate degree

0.725

$[0.183]^{* * *}$

0.106

[0.125]

0.219

[0.137]

0.215

Income $\$ 75,000-99,999$

[0.135]

Income $\$ 100,000-149,999$

0.253

[0.144]*

0.256

[0.188]

0.096

Unemployed

[0.184]

$-0.08$

[0.205]

0.015

[0.125]

0.115

Homemaker

[0.141]

0.177

Other

[0.194]

$\mathrm{N}$ obs

R-squared

0.48

F-statistic first stage regression 4.12

Note: Robust standard errors in brackets; ${ }^{* *} \mathrm{p}<0.01,{ }^{* *} \mathrm{p}<0.05,{ }^{*} \mathrm{p}<0.1$. Control for missing income also included. 
Table 9. Robustness Checks: Alternative Models and Samples

\section{A. Excluding Randomized Questions}

\begin{tabular}{lrr} 
& OLS & IV \\
\hline Advanced Financial Literacy Index & 0.122 & 0.397 \\
& {$[0.064]^{*}$} & {$[0.109]^{*}$} \\
Basic Financial Literacy Index & -0.08 & -0.182 \\
& {$[0.056]$} & {$[0.247]$} \\
Other controls & Yes & Yes \\
N obs & 989 & 936 \\
R-squared & 0.37 & \\
Hansen J test p-value & & 0.0396 \\
F-statistic first stage regression & & 4.89 \\
\hline
\end{tabular}

\section{B. Restricting Sample to < Age 62}

\begin{tabular}{lrr} 
& OLS & IV \\
\hline Advanced Financial Literacy Index & 0.2 & 0.407 \\
& {$[0.067]^{* * *}$} & {$[0.118]^{*}$} \\
Basic Financial Literacy Index & -0.13 & -0.207 \\
& {$[0.061]^{* *}$} & {$[0.292]$} \\
Other controls & Yes & Yes \\
N obs & 772 & 729 \\
R-squared & 0.43 & \\
Hansen J test p-value & & 0.0658 \\
F-statistic first stage regression & & 4.26 \\
\hline
\end{tabular}

\section{Sample Excluding Completely Retired}

\begin{tabular}{lrr} 
& OLS & IV \\
\hline Advanced Financial Literacy Index & 0.188 & 0.481 \\
& {$[0.068]^{* * *}$} & {$[0.277]^{*}$} \\
Basic Financial Literacy Index & -0.102 & -0.217 \\
& {$[0.063]$} & {$[0.119]^{*}$} \\
Other controls & Yes & Yes \\
N obs & 803 & 758 \\
R-squared & 0.41 & \\
Hansen J test p-value & & 0.056 \\
F-statistic first stage regression & & 4.28 \\
\hline
\end{tabular}




\begin{tabular}{|c|c|c|}
\hline Variable & Mean & St. Dev. \\
\hline Age & 45.01 & 16.20 \\
\hline Male & 0.48 & 0.50 \\
\hline \multicolumn{3}{|l|}{ Marital status } \\
\hline Married & 0.60 & 0.49 \\
\hline Separated & 0.02 & 0.13 \\
\hline Divorced & 0.11 & 0.31 \\
\hline Widowed & 0.06 & 0.24 \\
\hline Single & 0.21 & 0.41 \\
\hline \multicolumn{3}{|l|}{ Highest Education Completed } \\
\hline $1-12^{\text {th }}$ grade no diploma (coded as 11 years) & 0.06 & 0.24 \\
\hline High school graduate (12) & 0.23 & 0.42 \\
\hline Some college but no degree (14) & 0.18 & 0.39 \\
\hline Assoc/Occ/Voc (15) & 0.07 & 0.25 \\
\hline Bachelors degree (16) & 0.26 & 0.44 \\
\hline Masters degree (17) & 0.17 & 0.37 \\
\hline Doctorate degree (20) & 0.03 & 0.18 \\
\hline \multicolumn{3}{|l|}{ Total combined income } \\
\hline$<\$ 25,000$ & 0.20 & 0.40 \\
\hline$\$ 25,000-50,000$ & 0.27 & 0.45 \\
\hline$\$ 50,000-75,000$ & 0.21 & 0.40 \\
\hline$\$ 75,000-100,000$ & 0.09 & 0.29 \\
\hline$\$ 100,000-150,000$ & 0.12 & 0.33 \\
\hline$>\$ 150,000$ & 0.09 & 0.29 \\
\hline Refused & 0.01 & 0.10 \\
\hline \multicolumn{3}{|l|}{ Labor Force Status } \\
\hline Working & 0.64 & 0.48 \\
\hline Unemployed & 0.03 & 0.18 \\
\hline Temporarily laid off, on leave & 0.01 & 0.10 \\
\hline Disabled & 0.04 & 0.21 \\
\hline Retired & 0.17 & 0.38 \\
\hline Homemaker & 0.06 & 0.24 \\
\hline Other & 0.05 & 0.22 \\
\hline \multicolumn{3}{|l|}{ Retirement Status } \\
\hline Completely retired & 0.16 & 0.37 \\
\hline Partly retired & 0.06 & 0.24 \\
\hline Not retired & 0.70 & 0.46 \\
\hline Not applicable (homemaker, stop working $<$ age 50 ) & 0.07 & 0.26 \\
\hline
\end{tabular}

$\mathrm{N}$ obs=989; sample weighted. Source: Authors' derivation from the RAND American Life Panel (ALP); see text. 


\section{Appendix Table 2. Constructing the Financial Literacy Index: Factor Loadings}

The two summary financial literacy indices are based on responses to the five basic and eight sophisticated financial literacy questions discussed in the text. For each question we construct a dummy variable indicating which respondents answered the question correctly. We then perform factor analysis on those binary variables using the principal component factor method; factor loadings are presented below. We retain one factor that summarizes respondent financial literacy using factor scores derived with the Bartlett (1937) method.

\begin{tabular}{lr}
\hline Basic Financial Literacy Questions & Factor loadings \\
Numeracy & 0.4422 \\
Compound interest & 0.3195 \\
Inflation & 0.3744 \\
Time value of money & 0.3120 \\
Money illusion & 0.1668 \\
\hline
\end{tabular}

\section{Sophisticated Financial Literacy Questions}

Stock market function

Knowledge of mutual funds

Bond prices and interest rates

Safer: company stock or stock mutual fund?

Riskier: stocks or bonds?

Higher LR return: stocks or bonds

Highest fluctuations over time

Risk diversification
Factor loadings

0.1447

0.3250

0.0995

0.2712

0.1273

0.2338

0.1486

0.2774 